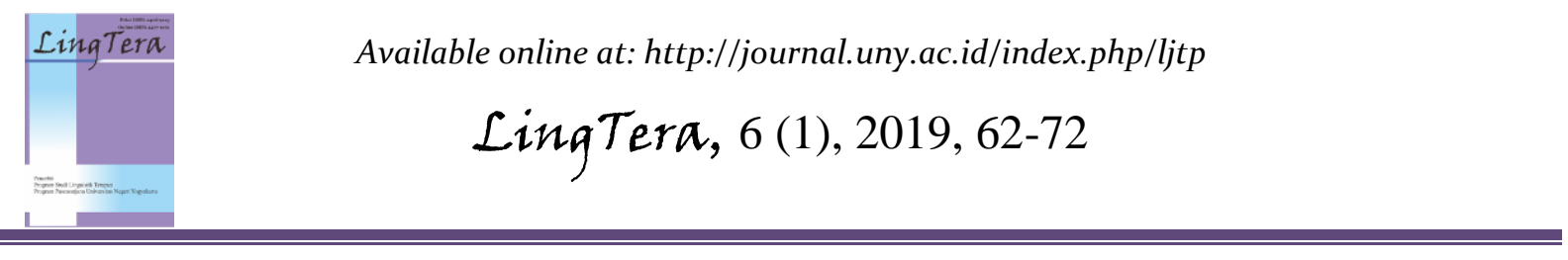

\title{
Autonomous learning materials of structure and written expression for TOEFL preparation
}

\author{
Aung Si Thu \\ Ministry of Religious Affairs and Culture, Myanmar \\ *Corresponding author. Email aungsithu.99999@ gmail.com \\ Received: 25 September 2017; Revision: 13 May 2019; Accepted: 16 September 2019
}

\begin{abstract}
This study aimed to develop appropriate autonomous learning materials of structure and written expression of TOEFL preparation for autonomous learners for the Centre for Language and Development of Yogyakarta State University based on the learning needs and target needs of the autonomous learners. The research was educational research and development (R\&D) adapting ADDIE model (Branch, 2009). Two instruments (questionnaire and test) for needs analysis and two instruments for validation were used. The data from the needs analysis and the material validation were analysed quantitatively through descriptive statistics. The research findings revealed that the autonomous learning materials were appropriate in terms of input, learning activities, layout, design and organisation. The learners' role is to learn the materials individually, and the teacher's role is to be a guide and cooperator. All of the learning activities include reading explanations of forms and functions, doing practices for forms and functions, multiple-choice, and doing reflection. Every unit has the following organising unit title, instructions for learners, grammatical form and functions, activities of forms, functions, and TOEFL tests items, online activities for further learning, learning essentials, reflection, self-test (TOEFL) and answer keys.
\end{abstract}

Keywords: autonomous learning, materials, learning TOEFL preparation

How to Cite: Thu, A. (2019). Autonomous learning materials of structure and written expression for TOEFL preparation. LingTera, 6(1), 62-72. doi:https://doi.org/10.21831/lt.v6i1.15919

This is an open access article under the CC-BY-SA license.

\section{INTRODUCTION}

Autonomous learning has been considered as an essential part of learning in the last ten years based on the learners themselves, their needs, interests and reasons to learn a subject (Cole \& Vanderplank, 2016; Shangarffam \& Ghazi Saeedi, 2013). In the most recent 2013 Curriculum, the teaching and learning process is expected to support students in the learning process, and students also have to study theirself. The scientific approach and problem-solving activities are to be utilised in the teaching and learning process (Lengkanawati, 2017; Luo \& $\mathrm{Xu}, 2019)$. This implies that autonomous learning is now considered to be fundamental in the teaching and learning process. In Indonesian contexts, autonomous learning refers to a situation where students use language-learning strategies to make themselves become autonomous learners (Lengkanawati, 2017).
In EFL learning for autonomous learners, (Gardner, 2011; Najeeb, 2013; Tian \& Chunlei, 2005) said that EFL teachers who work in the self-directed and self-access for autonomous learners have to provide the students with knowledge of learning strategies, learning materials, learning resources. In some Indonesian universities, there are autonomous learning environment and autonomous learning materials for the autonomous learners at Self-directed or Selfaccess Language Centers. Therefore, autonomous learning for EFL in Indonesia gradually is familiar with the students in Indonesia.

In Indonesia, the self-directed and selfaccess language centres for autonomous learning provide many services such as self-access learning materials, learning resources, language learning advising. In the Yogyakarta State University, the Independent Language Learning Centre (ILLC) in the Centre for Language Development also provides the language leaning 
facilities and services, self-access learning materials such as TOEFL, IELTS, TOIEC, Reading, Listening, Grammar, etc.), TOEFL \& IELTS preparation, etc.

In Indonesia, the TOEFL test is highly recommended for students who want to continue their education to a higher level, for example, from undergraduate level to graduate level. Taking TOEFL test is considered difficult. Consequently, many test-takers failed the test and did not reach the standard passing grade (Boulet, van Zanten, McKinley, \& Gary, 2001; Mahmud, 2014).

TOEFL in ILLC also is more important than others because the TOEFL test is for the essential test of the requirement to obtain the degree. TOEFL test is highly recommended for students who want to continue their education to higher level, for example, from undergraduate level to graduate level. But, not reached the required score.

Autonomous learning materials of TOEFL can help not only the teachers but also the students to get appropriate materials of TOEFL preparation. There is so many TOEFL TEST which are TOEFL PBT, TOEFL CBT, TOEFL IBT, and TOEFL ITP test. Among them, The TOEFL ITP tests are conducted by most of Indonesia universities, including Yogyakarta State University. In TOEFL ITP, there are three sections of test, namely, listening comprehension, structure and written expression and reading compression.

Structure and written expression is an important section, and some of the students face the difficult to learn. They need to study the structure and written expression materials. On the other hand, the autonomous learning materials of structure and written expression of TOEFL preparation is easy for the beginner of autonomous learning to learn learning materials for grammar. Therefore, the research focus on the sections of the structure and written expression of the TOEFL.

Out of the lack of the autonomous learning materials, the researcher finds what kinds of structures and written expression are the difficulties of learners in preparing TOEFL in particular and what kinds of materials and what makes them difficult to study. In developing autonomous learning materials of structure and written expression for TOEFL preparation, the researcher design the appropriate autonomous learning materials for the autonomous learners to learn independently. Moreover, the autonomous learning materials of structure and written expression for the TOEFL preparation were developed with grammatical form, grammatical function (Nordquist, 2011; Phillips, 2001; Purpura, 2013; Saryati \& Yulia, 2019).

\section{METHOD}

It is important to seek for methods that autonomous learners adapt easily to achieve what they learn. So, the researcher used the quantitative technique. Participants are 29 students who study the TOEFL preparation at Independent Language Learning Centre (ILLC) in the Centre for Language Development of Yogyakarta State University to get the required scores of TOEFL. In this study, the researcher used two instruments for needs analysis which are questionnaire and test for structure and written expression to find the lack of the skills. For validation of the autonomous learning materials, two instruments were used including content, Presentation, learning activities, layout and design. The procedures of the research have five stages adapted ADDIE model (Branch, 2009) namely, conducting analysis, designing materials, developing materials, implementation materials and evaluation. The conducting analysis stage is doing pre-survey, analysis instruments, validating the instruments and collecting the. In the designing stage, data from the needs analysis were analysed quantitatively through descriptive statistics using formula, and this study had used designing autonomous learning materials based on (Cook, 1993; Cooker \& Pemberton, 2010; Nunan, 2004) Tomlison, (2008. After developing the materials and validating the materials, first draft product tried out five times in the TOEFL preparation class of ILLC. The evaluation stage was reviewing the materials according to the result of the tryout.

\section{FINDINGS AND DISCUSSIONS}

The results of this study show that the primary necessaries of the skills of learners were using pronouns, using the preposition, using the adverb, noun clause and adjective clause, making reduced clause, making infinitive clause, making the parallel structure, making comparative and superlatives, using the article and daily usages.

Based on the students' needs, the skills and activities, input, learners' role, teachers' role and time, the autonomous learning materials of structure and written expression are developed. When the autonomous learning materials were developed, the researcher also considered not 
Aung Si Thu

only the target needs, learning need but also grammatical form and functions of the TOEFL and autonomous learning aspects which are related to the kind of learning strategies in cognitive and metacognitive approaches according to the theoretical review. Therefore, all units were made grammatical form of particular skill, grammatical function of the particular skill, activities (task-based) for particular skill, which provides to get skill in the structure and written expression, the internet address to enriches student's knowledge and skill in the grammar and these materials have been from the internet to enhance students' ability, learning essential to describes the primary subject of the unit, learning review to brings to students in the form of questions that remind students of some learning materials, self-test to practice the skills according to the TOEFL questions types and answer keys. Moreover, there are some explanations for autonomous learners which is how to learn it autonomously.

Figure 1 presents the needs of the learners. The bar chart illustrates that the students studying the Tutorial pro-TOEFL Remidi Intensity course at ILLC and skills of the structure and written expression to know the necessities of students in structure and written expression for TOEFL.

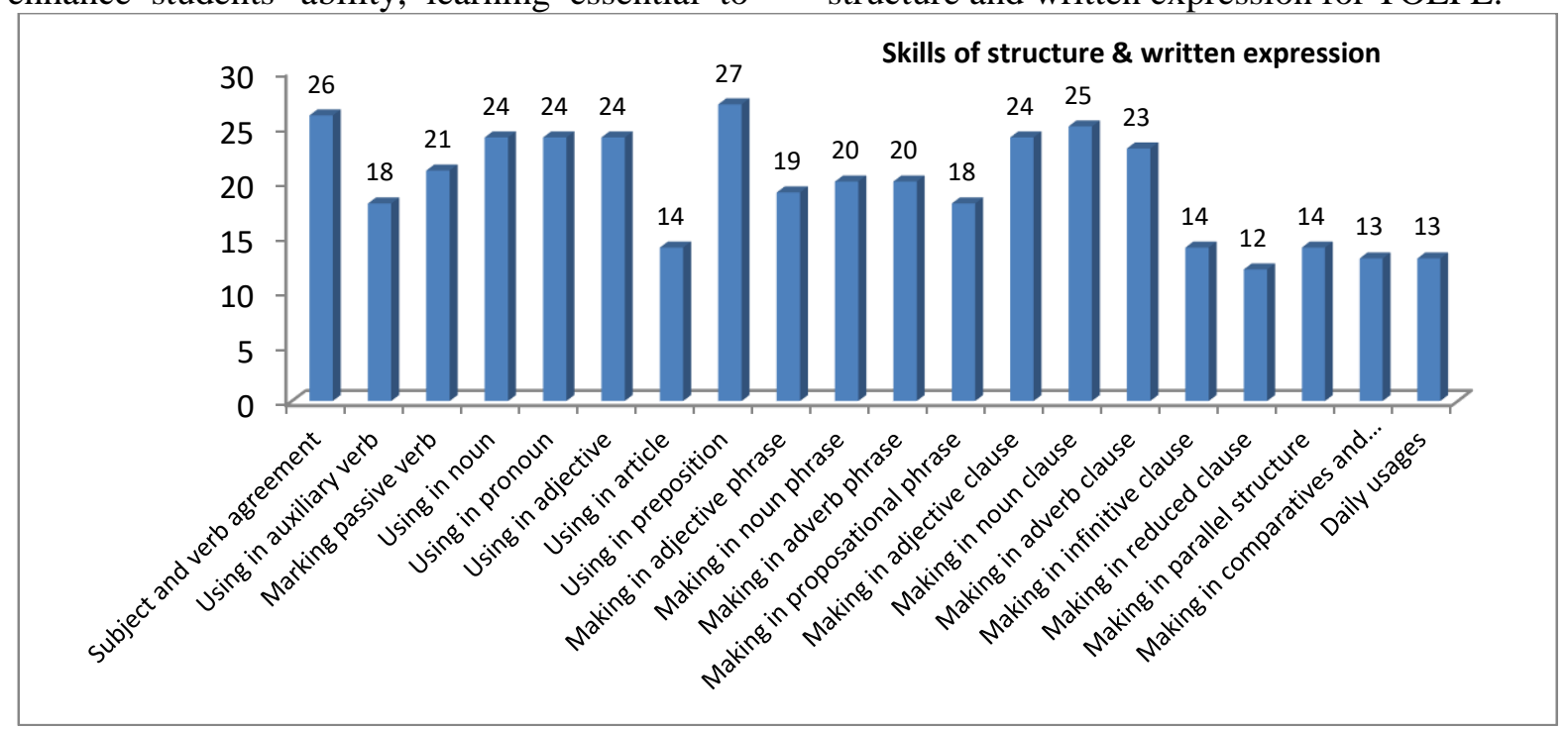

Figure 1. Students' necessaries of skills of structure and written expression

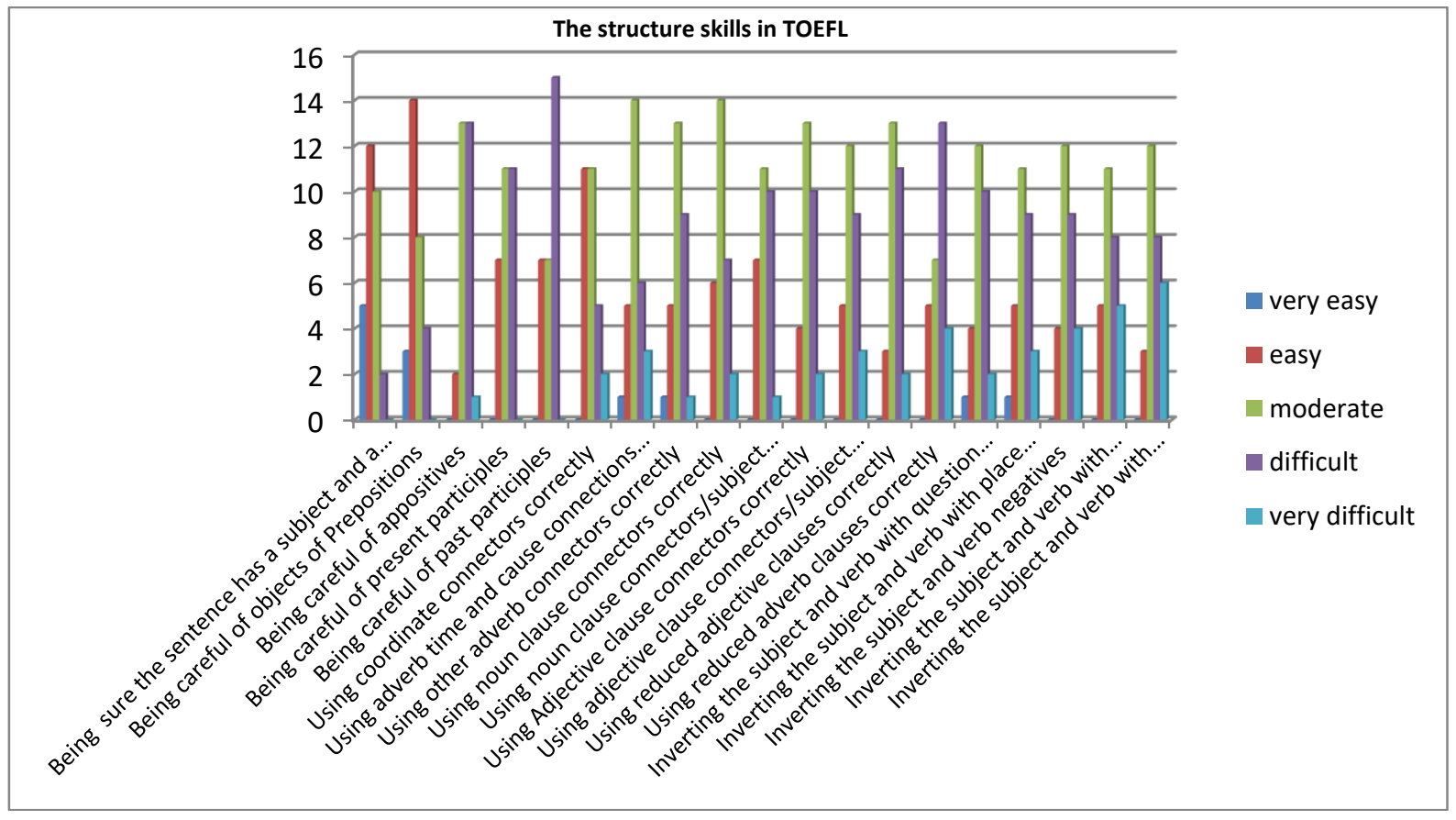

Figure 2. Summary of Lack of the students in 'Structure' from questionnaires 
Aung Si Thu

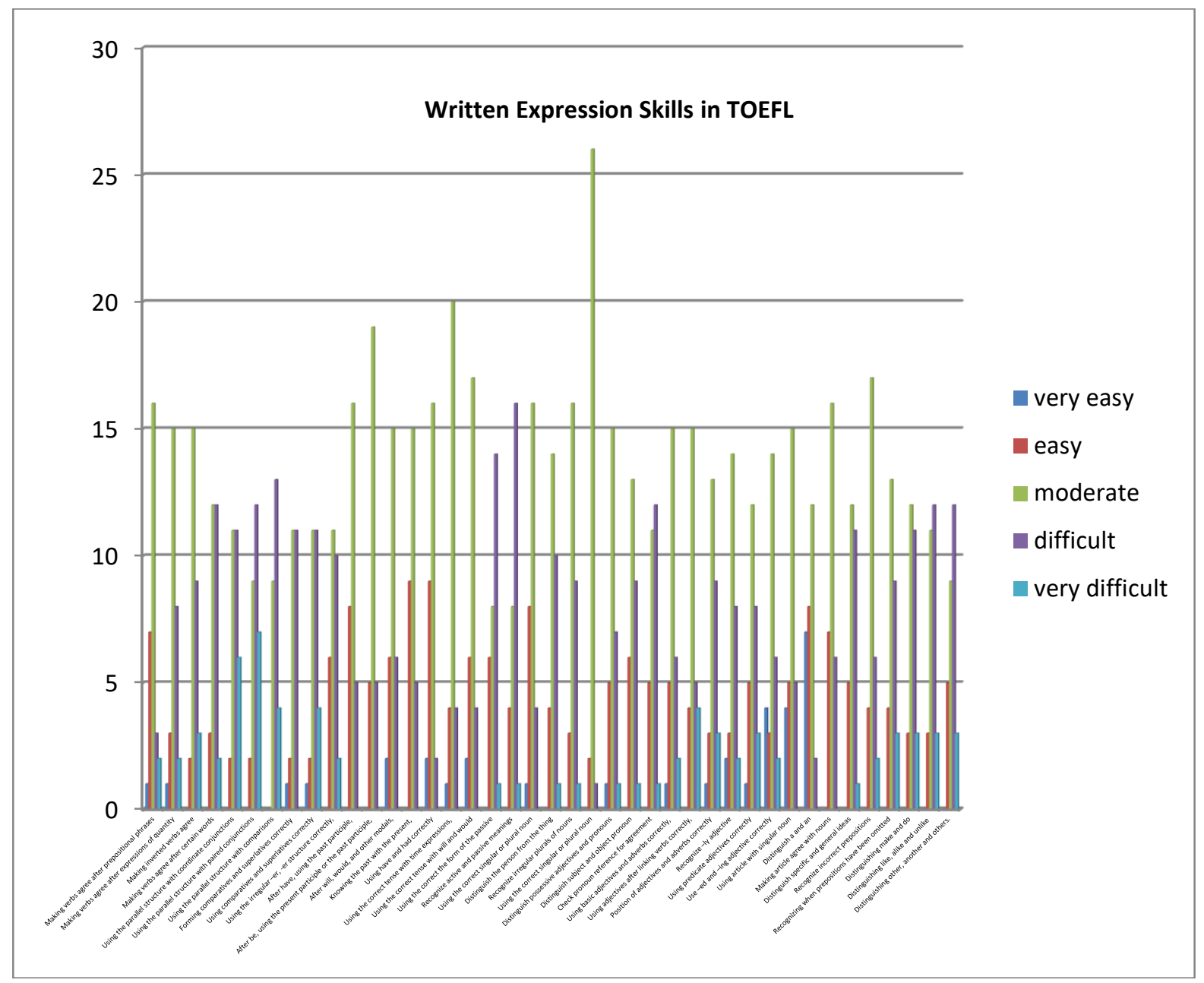

Figure 3. Summary of Lack of the students in 'written expression' from questionnaires

According to the Figure 1, it can be seen that in a subject and verb agreement of the skill of structure and written expression, 26 students $(89.7 \%)$ of 29 learners who answered 'yes'. It means that 26 students $(89.7 \%)$ know that a subject and verb agreement are tested in TOEFL. It can be seen that in using auxiliary verb, 18 students $(62.1 \%)$ of 29 learners who answered 'yes', 21 students $(72.4 \%)$ in the marking passive verb, 24 students $(82.8 \%)$ in using noun, 24 students $(82.8 \%)$ in using pronouns, 24 students $(82,8 \%)$ in using the adjective, 14 students (48.3\%) in using the article, 27 students (93.1\%) in using in preposition, 19 students $(65.5 \%)$ in making the adjective phrase, 20 students $(69.0 \%)$ in the making in noun phrase, 20 students (69.0\%) in making the adverb phrase, 18 students $(62.1 \%)$ in making proposition phrase, 24 students $(82.8 \%)$ in making the adjective clause making, 25 students $(86.2 \%)$ in making the noun clause, 23 students $(79.3 \%)$ in making the adverb clause making, 14 students $(48.3 \%)$ in the making infinitive clause, 12 students $(41.4 \%)$ in the making reduced clause, 14 students $(48.3 \%)$ in making the parallel structure, 13 students $(44.8 \%)$ in the making comparative and superlatives and 13 students (44.8\%) in daily usages.

Overall, we can see a clear upward trend in the skills of subject and verb agreement, using in preposition, making noun clause, making adjective clause, making adverb clause, using in noun, pronoun and adjective and using in auxiliary verb, while the skills of making infinitive clause, making reduced clause, making parallel structure, making comparative and superlatives, using article and daily usages are seen to have levelled off.

According to the Figure 2, the difficulties of the students in the structure are that 15 of 29 students said that 'being careful of past participle is difficult, 13 students 'using reduced adverb clause is difficult, 10 of 29 students 'using noun clause and using adjective clause and Using reduced adverb clauses correctly. 6 and 5 students of 29 students said that the most difficulties of the students were 'Inverting the 
subject and verb with conditionals and inverting the subject and verb with the comparison.

According to the Figure 3, the difficulties of the students in structure are that 16 of 29 students said that 'recognize active and passive meanings 'is difficult, 14 students 'using the correct the form of the passive is difficult, 13 of 29 students 'using the parallel structure with comparisons', 12 of 29 students 'Using the parallel structure with coordinate conjunctions and using the parallel structure with paired conjunction. 4 and 3 students of 29 students said that the most difficulties of the students were 'using the parallel structure with comparisons, the position of adjectives and adverbs correctly, recognising when prepositions have been omitted and distinguishing like, alike and unlike.

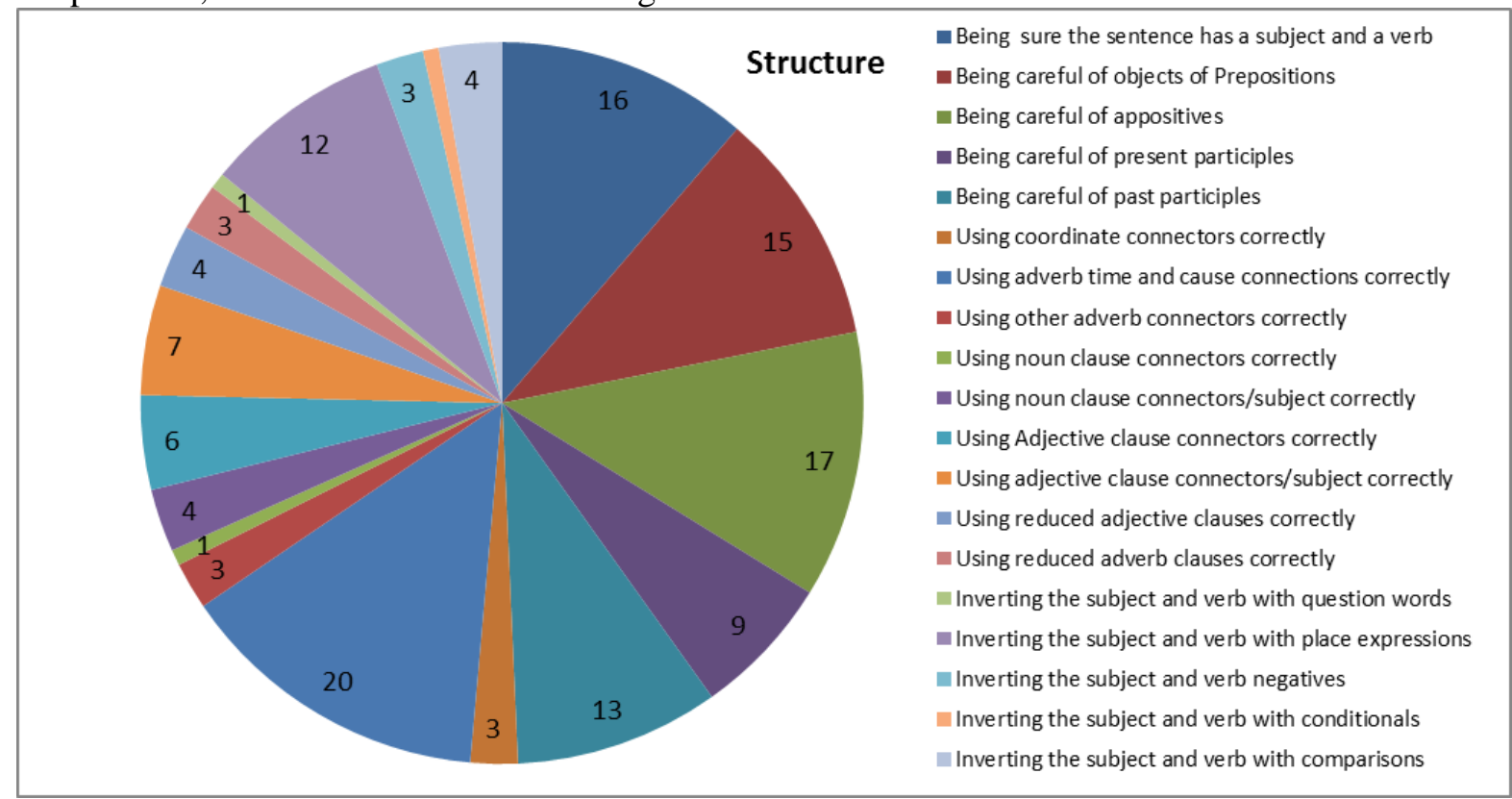

Figure 4. Summary of the lacks for structures from Test

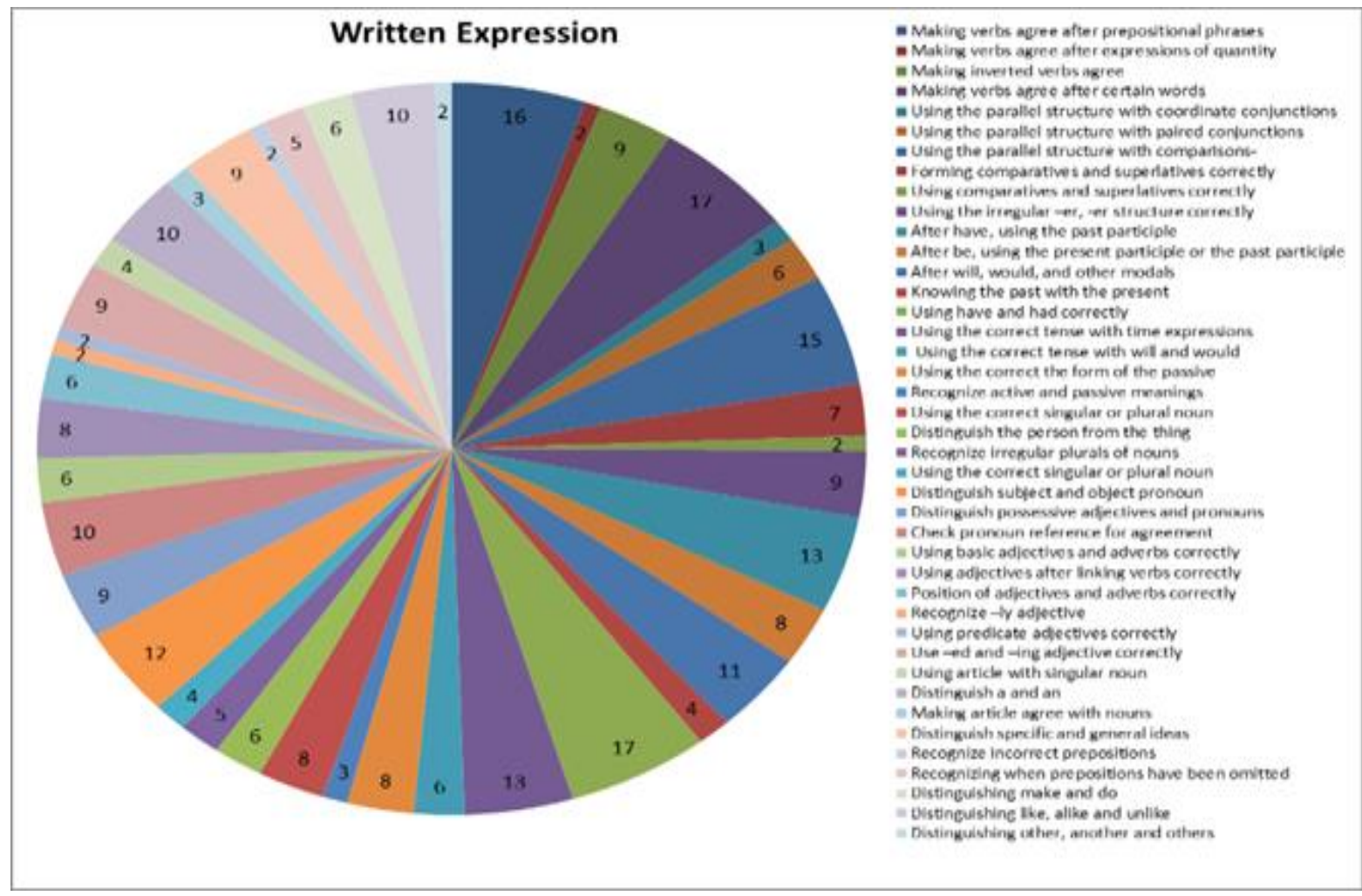

Figure 5. Summary of the lacks for structures from Test 
Aung Si Thu

According to the whole test of the structure in TOEFL, I can find that among the 19 microskills, most of the difficulties of the students are "using noun clause connectors correctly, inverting the subject and verb with question words and inverting the subject and verb with conditionals" because one student $(3.4 \%)$ of 29 students can answer correctly.

In the conclusion of the test for written expression, the researcher fine that among the 41 skills, the most difficulties of the students are " Making verbs agree after certain words, Using the irregular -er, -er structure correctly, Recognize -ly adjective, Using adjectives after linking verbs correctly, Recognize incorrect prepositions and Distinguishing other, another and others " because two students (6.9\%) of 29 students can answer correctly.

According to Table 1, 5 (17.2\%) students chose the sentence with multiple clauses five times, parallel structure three times and 6 $(20.7 \%)$ students chose daily usage six times.

According to Figure 6, students chose article form journals (science) six times, new stories and reports five times, science book threetime, art book and picture stories or explaining the grammar structure.

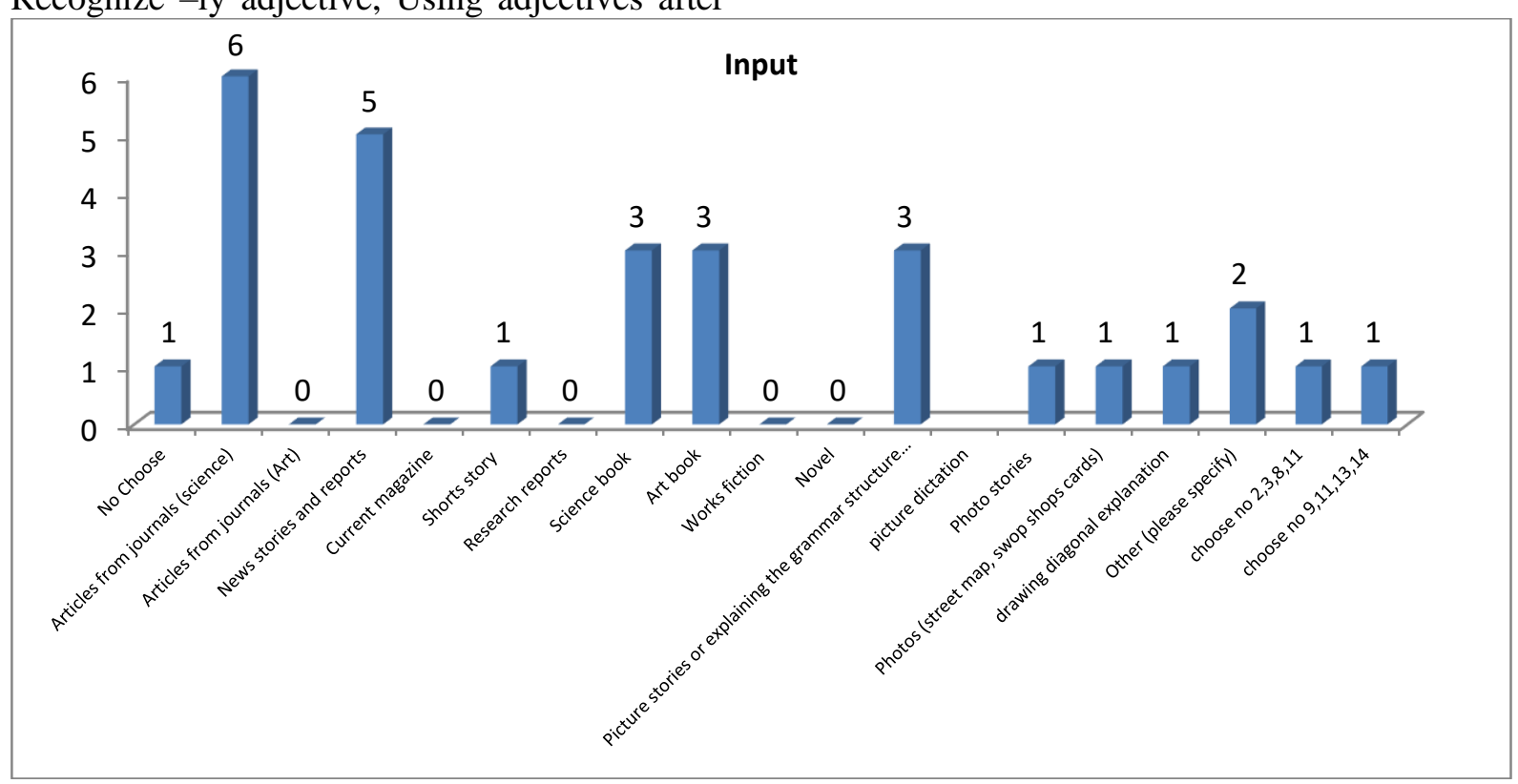

Figure 6. The input of the materials which students prefer

Table 1. Wants of the Students

\begin{tabular}{|c|c|c|c|c|c|}
\hline \multicolumn{6}{|c|}{ Skills } \\
\hline & & Frequency & Percent & Valid Percent & Cumulative Percent \\
\hline \multirow[t]{15}{*}{ Valid } & No Choice & 1 & 3.4 & 3.4 & 3.4 \\
\hline & Sentence with one clause & 3 & 10.3 & 10.3 & 13.8 \\
\hline & Sentence with multiple cause & 5 & 17.2 & 17.2 & 31.0 \\
\hline & Sentence with inverted subject $\&$ verb & 1 & 3.4 & 3.4 & 34.5 \\
\hline & Parallel structure & 3 & 10.3 & 10.3 & 44.8 \\
\hline & Comparatives and superlative & 1 & 3.4 & 3.4 & 48.3 \\
\hline & Using verb & 2 & 6.9 & 6.9 & 55.2 \\
\hline & Using noun & 1 & 3.4 & 3.4 & 58.6 \\
\hline & Using pronoun & 1 & 3.4 & 3.4 & 62.1 \\
\hline & Using adjective & 1 & 3.4 & 3.4 & 65.5 \\
\hline & Using preposition & 2 & 6.9 & 6.9 & 72.4 \\
\hline & Daily usage & 6 & 20.7 & 20.7 & 93.1 \\
\hline & Choose no $1-15$ & 1 & 3.4 & 3.4 & 96.6 \\
\hline & All choose & 1 & 3.4 & 3.4 & 100.0 \\
\hline & Total & 29 & 100.0 & 100.0 & \\
\hline
\end{tabular}


LingTera,6 (1), 2019 - 68

Aung Si Thu

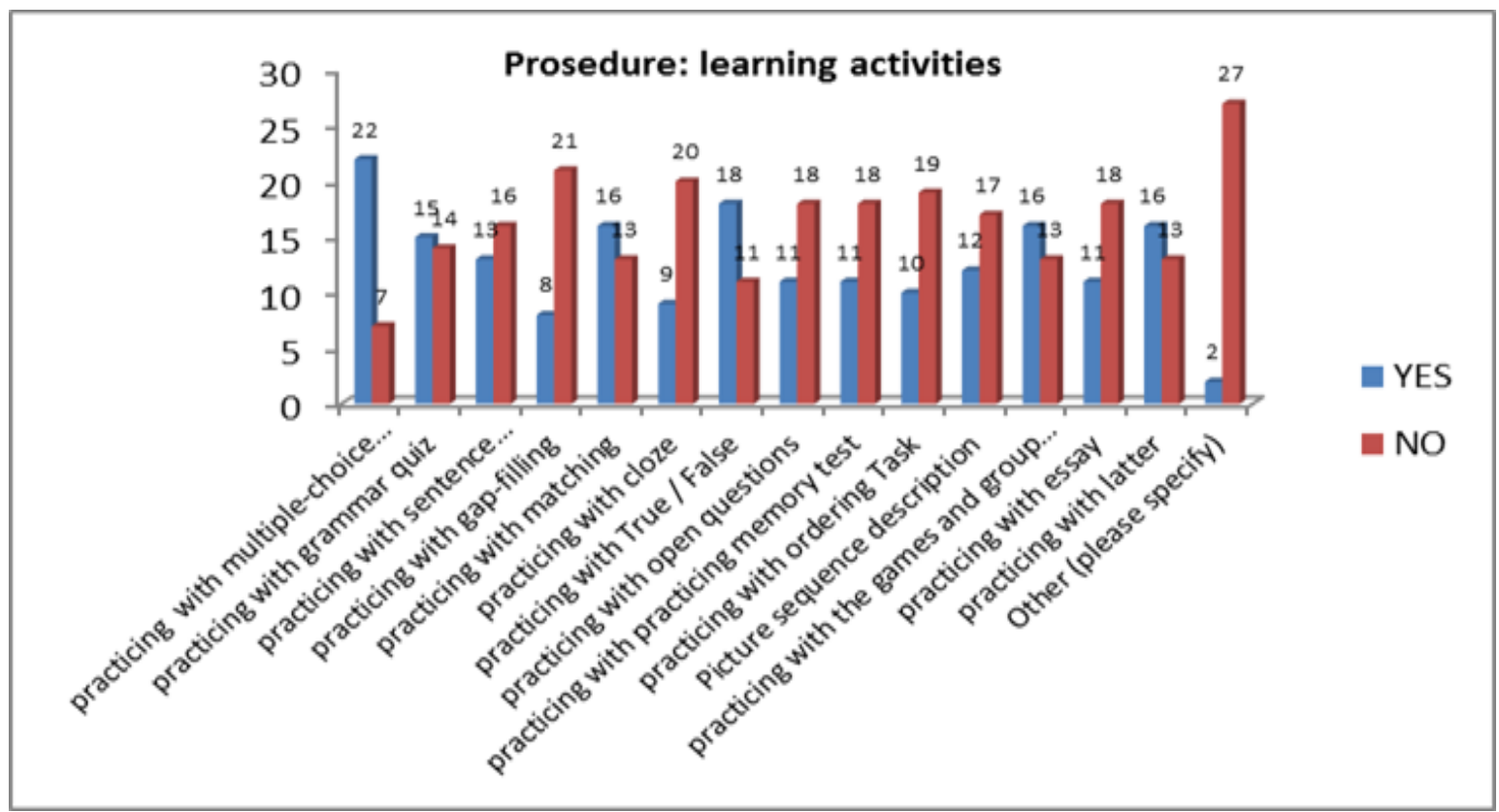

Figure 7. Learning Activities of the Learners

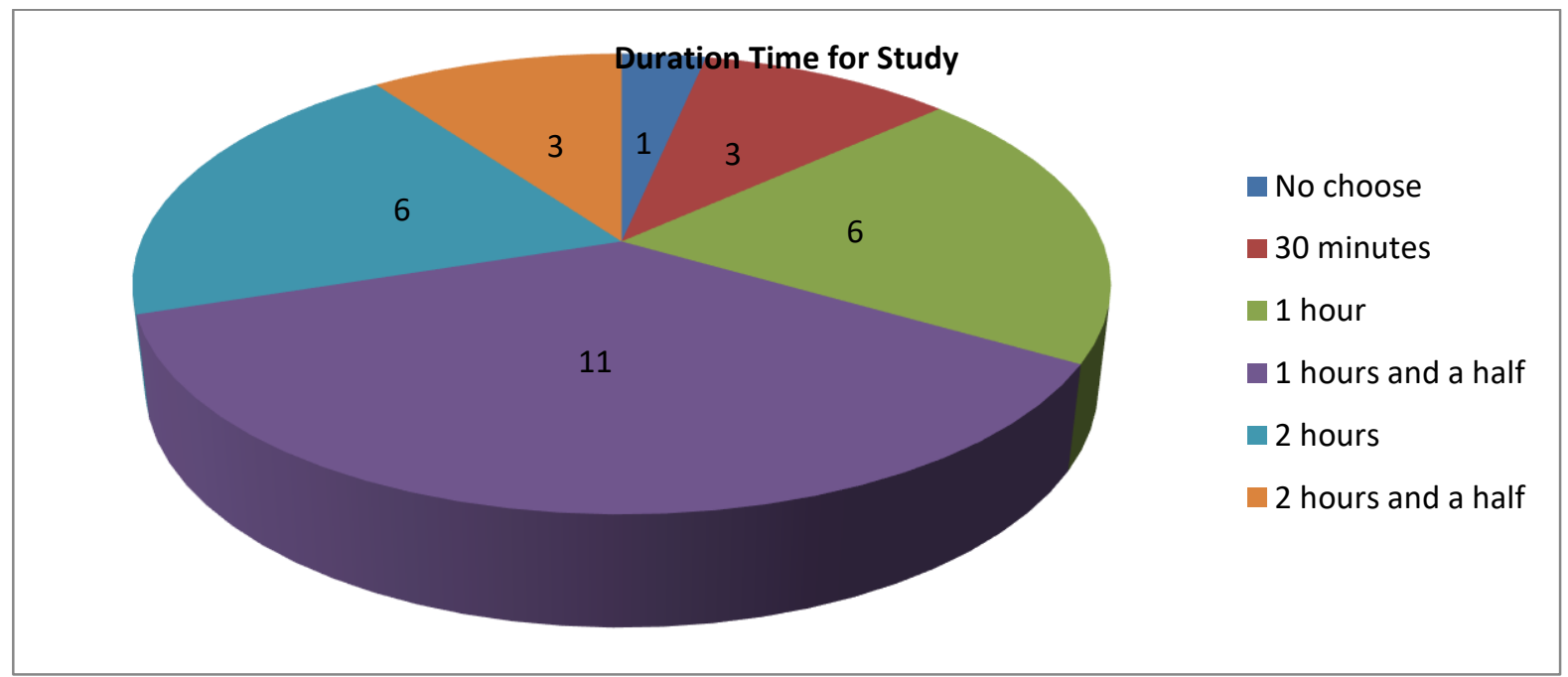

Figure 8. Length of the Study of the Learners

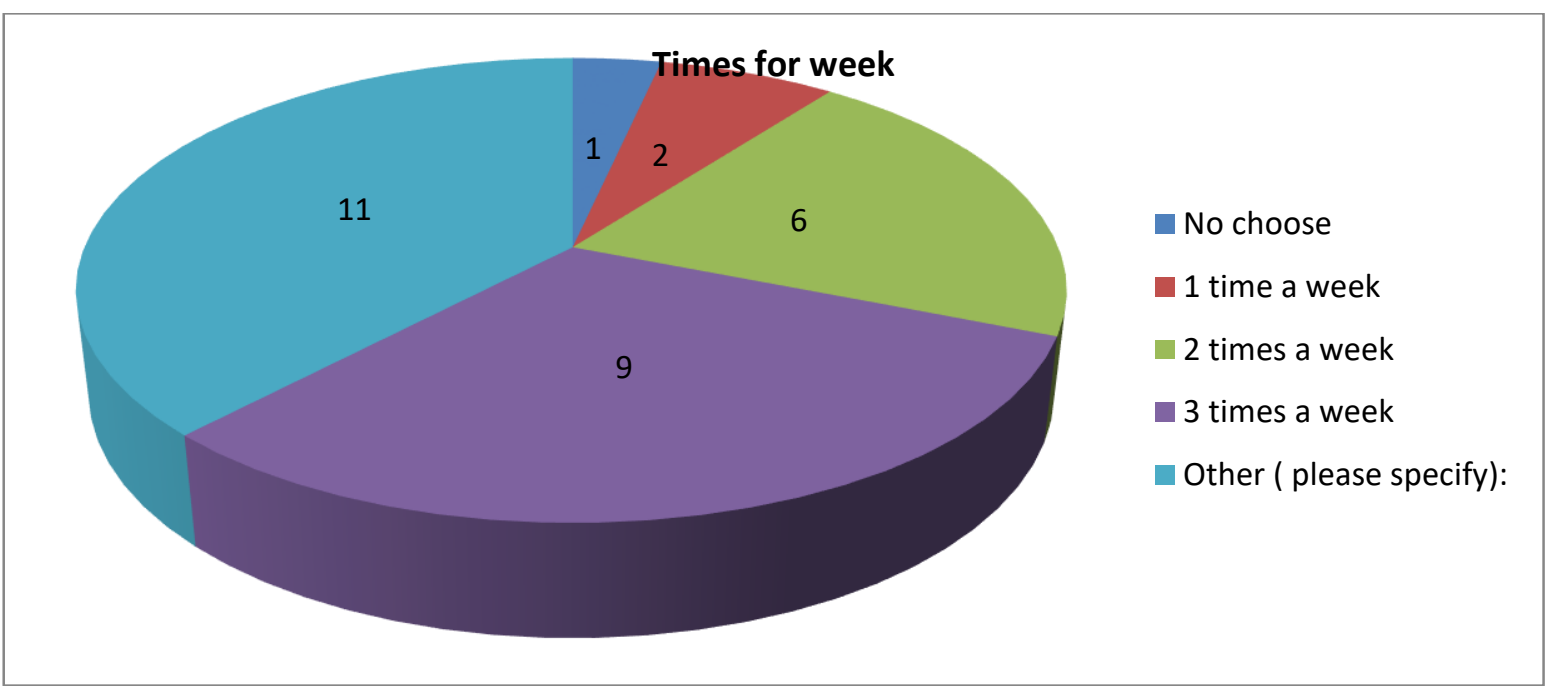

Figure 9. Study time per week 


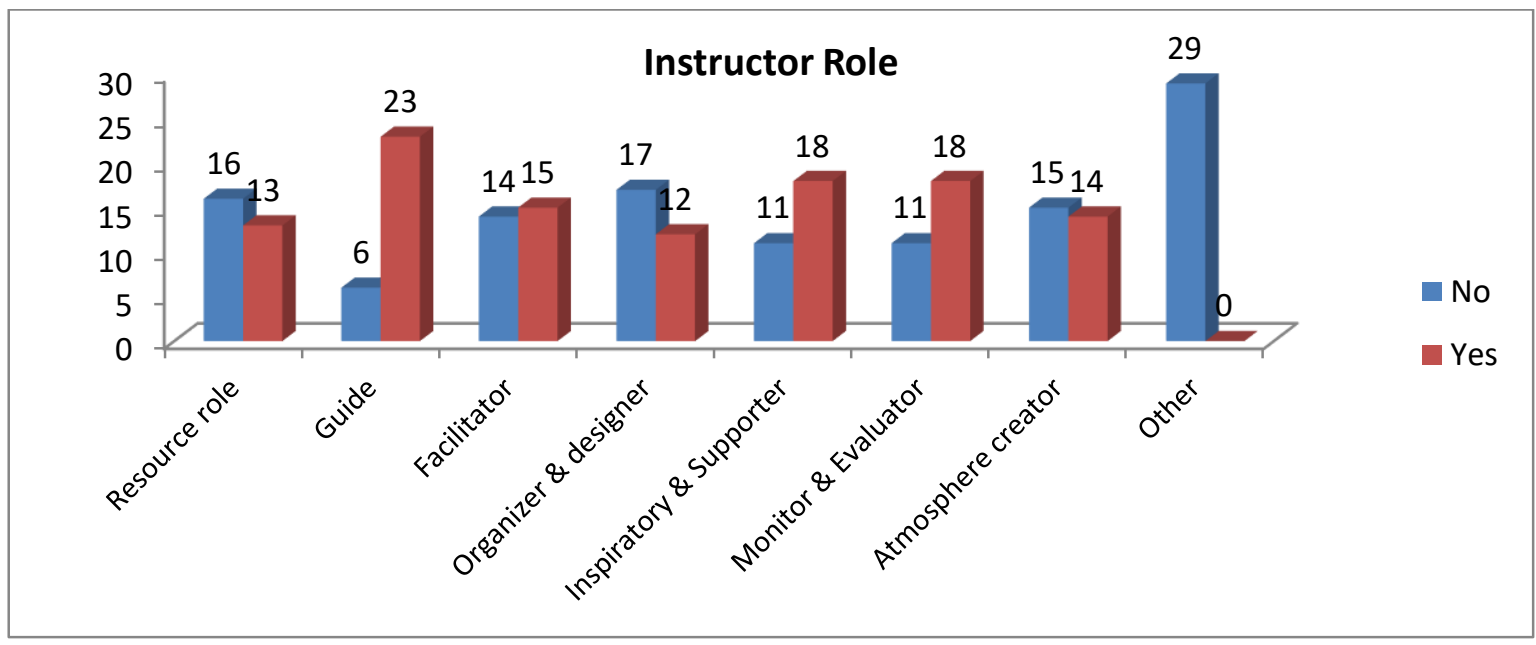

Figure 10. Instructor role which students prefer

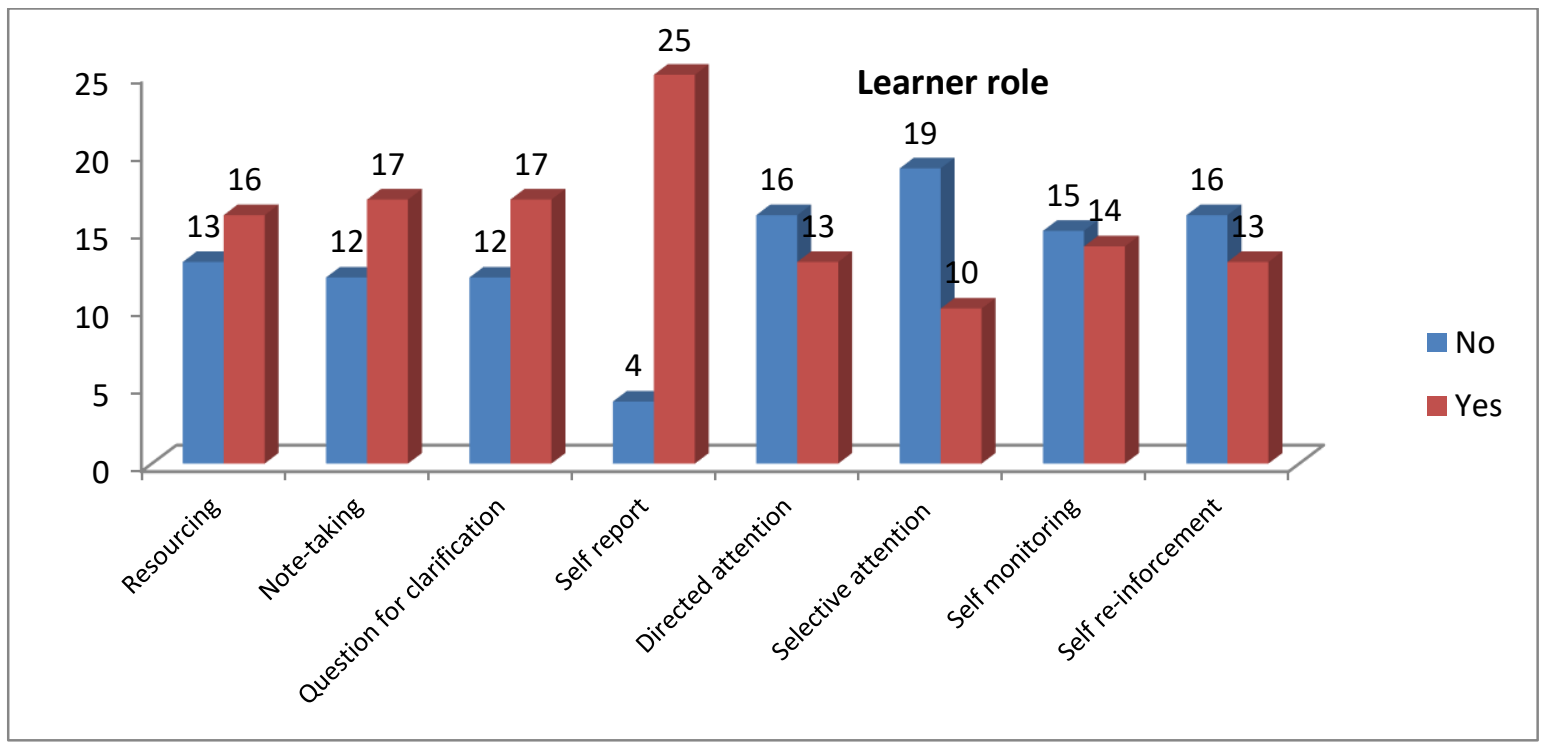

Figure 11. Instructor role which students prefer

According to the Figure 7, 29 students prefer 'practising with multiple-choice (TOEFL) twenty-two times', students practising with True/False' eighteen times, 'practising with latte, practising with matching and practising with the games and group discussion' sixteen times, 'practising with sentence transformation thirteen times, practising with open questions, practising with practising memory test and practising with essay' eleven times.

In Figure 8, 11 of 29 students said that they want to study the autonomous learning materials for one hour and a half, six students like to study it for an hour or 2 hours.

In Figure 9, 9 of 29 students said that they want to study the autonomous learning materials three times per week, six students like to study it two times per week.

In Figure 10, 16 of 29 students want the instructor to be a resource supplier, 17 students want the instructor to become an organiser \& designer (Organizing some communicative activities to get students to have more chances to practice English), 15 students want them to be an atmosphere creator. 11 students want them to be a Inspiratory \& Supporter ( Stimulating students' interest and enthusiasm in English learning; encouraging students to use English; motivating students to participate in communicative activities; encouraging students to do more speaking in English) and Monitor \& Evaluator (Providing students with feedback of their performance in the process of English learning as well as some guidance.

25 of 29 students want to write self-report, 17 students want to do note-taking and question for clarification, 15 students want them to be an atmosphere creator. Fourteen students like selfmonitoring, 13 students, want to create directed attention (when deciding in advance to 
concentrate on general aspects of a task) and ten students like selective attention (paying attention to specific aspects of a task).

The researcher developed the first draft materials based on the needs analysis and literature review. In the first draft of materials, the researcher developed five Units for five skills of the structure and written expression based on the skills of the structure and written expression in TOEFL of the literature review. The researcher made the components and unite organisation with form, functions, activities, further study, learning essential, reflection, self-test and answer keys.

\section{Form}

According to the literature review, grammatical form is how to make the word, phrases and clauses, so the researcher developed that in the form, there is the structure of a grammar point and practice of the form builds students' accuracy and helps them recognize the grammar point in authentic situations (Tomlinson, 2008).

\section{Function}

For the grammatical function in the materials, the researcher made 'function' how to use a grammar point and practice of the function builds students' fluency and helps them apply the grammar point in the TOEFL test.

Further Studies

The internet address to enrich student's knowledge and skill in the grammar and these materials have been from the internet to enhance students' ability.

Learning Essential

Learning essential to describe the primary subject of the unit.

Reflection

Learning review to bring to students in the form of questions that reminds students of some learning materials.

Activities

According to (Cooker \& Pemberton, 2010; Nunan, 2004) from the literature review, all the activities of the tests tried to be made as samples of proficient users' performance, authentic samples of proficient "performance" and tasks linked to self-evaluation of performance on a task.
According to the principles of the developing autonomous learning materials (Cooker \& Pemberton, 2010), all activities of each unit also give opportunities for learners to do them individually and to do so in their own time and at their own pace. In this materials, the researcher used the learning strategies which are cognitive strategy, metacognitive strategy and memory-related strategy e.g. self-report, notetaking and 'learning essential' for cognitive strategy which can find 'Guide to Use this Book' of beginning of the materials, 'Reflection' used with the metacognitive, 'some form and function' used with memory-related strategy. Moreover, the researcher also put the 'Further Studies' because learners can learn the skills of structure and written expression by using the internet to get more information and practice according to the 'supporting aspects to get the autonomous learning' from the literature review.

This research developed the five units for the five skills of the structure and written expression of TOEFL namely, (1) using noun clause correctly, (2) inverting subject and verb with conditionals, (3) using the adjective clause connectors correctly,(4) recognizing -ly adjective, and (5) using parallel structure with coordinate conjunctions.

\section{CONCLUSION}

In conclusion, the researcher did some important things in the developing materials process, namely, the result of needs analysis of the autonomous learners, the syllabus, the first draft of the materials, the results of validation for materials and the final draft product.

The findings showed that the target needs of learners in Independent Language Learning Centre (ILLC) in learning the structure and written expression in TOEFL included making infinitive clause, making reduced clause, noun clause and adjective clause. The grammatical items lacking included the noun clause, adjective clause, inversion and -ly adjective. The learning needs of the learners included (1) the input materials based on the science, art, story, report and general English; (2) learning activities based on the multiple-choice (TOEFL), True or False, practicing memory test, and practicing with sentence transformation; (3) the length of the study time for one hour and a half; (4) the instructor as a guide, evaluator, and monitor, (5) the note-taking and the self-report for learners.

Based on the students' needs, the skills and activities, input, learners' role, teachers' role and 
time, the autonomous learning materials of structure and written expression are developed. When the autonomous learning materials were developed, the researcher also considered not only the target needs, learning need but also grammatical form and functions of the TOEFL and autonomous learning aspects which are related to the kind of learning strategies in cognitive and metacognitive approaches according to the theoretical review. Therefore, all units were made grammatical form of particular skill, grammatical function of the particular skill, activities (task-based) for particular skill, which provides to get skill in the structure and written expression, the internet address to enriches student's knowledge and skill in the grammar and these materials have been from the internet to enhance students' ability, learning essential to describes the primary subject of the unit, learning review to brings to students in the form of questions that remind students of some learning materials, self-test to practice the skills according to the TOEFL questions types and answer keys. Moreover, there are some explanations for autonomous learners which is how to learn it autonomously.

After developing the first draft of the autonomous learning materials, to know if they are appropriate, the researcher made the validation of instruments based on evaluation and approval of grammar for autonomous English learners (Gardner, 2011; Hosie, Schibeci, \& Backhaus, 2005; Prince Edward Island, 2008). The appropriateness of the developed materials has been evaluated by expert and learners. According to the result of the expert judgment, the product is 'Very Good", but the researcher has to review the autonomous learning materials according to the suggestion of expert. After that, the researcher tried out the materials five times. The result of the tryout is 'Very Good', but the researcher reviewed the materials based on the experience of tryout and difficulties of learners.

Therefore, it is appropriate that autonomous learning materials of structure and written expression based on the target needs and learning needs using the autonomous learning theories are not only for the autonomous learners who study in ILLC but also teachers who work in the autonomous learning process

There are implications based on the experience of this research and the finding of this study. Most of the students do not have the experience to study materials by using the target language. Because of that problem, the researcher had to try out his materials in classrooms. It means they need a teacher as the guide in the learning process. Therefore, further researchers should develop the autonomous learning materials using the target language as well as a mother tongue to explain some grammatical points for the beginner level and lowerintermediate level.

Most of the students want to learn autonomous learning materials based on online or study platform than with paper-based because they like technology if it is easy to use and understand it. Moreover, a further researcher should study how to improve the students' motivation in the learning process because some of the students did not do homework or assignments using the autonomous learning materials while the researcher tried out his materials.

For further research, the existence of autonomous materials of structure and written expression for TOEFL would be very important for the learners of ILLC because they can study independently in any place and anytime and all master students from UNY now need to get over 450 in pro-TOEFL Test. Also, the development of autonomous learning materials will be helpful to improve the structure and written expression in TOEFL. Finally, the further researcher should also consider developing autonomous learning materials of grammar for beginner level using with Indonesia language.

\section{REFERENCES}

Boulet, J. R., van Zanten, M., McKinley, D. W., \& Gary, N. E. (2001). Evaluating the spoken English proficiency of graduates of foreign medical schools. Medical Education, 35(8), 767-773. https://doi.org/10.1046/j.13652923.2001.00998.x

Branch, R. M. (2009). Instructional design: The ADDIE approach. New York, N.Y.: Springer Science \& Business Media.

Cole, J., \& Vanderplank, R. (2016). Comparing autonomous and class-based learners in Brazil: Evidence for the present-day advantages of informal, out-of-class learning. System, 61, 31-42. https://doi.org/10.1016/j.system.2016.07.0 07

Cook, V. (1993). Linguistics and second language acquisition. London: Macmillan.

Cooker, L., \& Pemberton, R. (2010). Self-access 


\section{LingTera,6 (1), 2019 - 72}

Aung Si Thu

language learning in museums: A materials development project. SiSAL Journal, 1(2), 87-99. Retrieved from http://sisaljournal.org/archives/sep10/coo ker_pemberton

Gardner, D. P. (2011). Fostering autonomy in language learning. Zirve University.

Hosie, P., Schibeci, R., \& Backhaus, A. (2005). A framework and checklists for evaluating online learning in higher education. Assessment \& Evaluation in Higher Education, 30(5), 539-553. https://doi.org/10.1080/026029305001870 97

Lengkanawati, N. S. (2017). Learner autonomy in the Indonesian EFL settings. Indonesian Journal of Applied Linguistics, 6(2), 222. https://doi.org/10.17509/ijal.v6i2.4847

Luo, Y., \& Xu, W. (2019). A review on the professional development of elementary education teachers in China. International Journal of Education and Learning, 1(2), 98.

https://doi.org/https://doi.org/10.31763/ije le.v1i2.56

Mahmud, M. (2014). The EFL students' problems in answering the Test of English as a Foreign Language (TOEFL): a study in Indonesian context. Theory and Practice in Language Studies, 4(12), 2581.

Najeeb, S. S. R. (2013). Learner autonomy in language learning. Procedia - Social and Behavioral Sciences, 70, 1238-1242. https://doi.org/10.1016/j.sbspro.2013.01.1 83

Nordquist, R. (2011). Grammar in English definition and examples glossary of grammatical and rhetorical terms. Retrieved from https://www.thoughtco.com/what-is- grammar-1690909 retrieved Dec 18, 2016

Nunan, D. (2004). Task-based language teaching. Cambridge University Press. https://doi.org/10.1017/cbo978051166733 6

Phillips, D. (2001). Longman complete course for the TOEFL test: Preparation for the computer and paper tests. London: Longman.

Prince Edward Island. (2008). Evaluation and selection of learning resource. Education and Early Childhood Development.

Purpura, J. E. (2013). Assessing grammar. In The Companion to Language Assessment (pp. 100-124). https://doi.org/10.1002/9781118411360.w bcla147

Saryati, T., \& Yulia, Y. (2019). Contextual teaching and learning approach to supplementary reading materials based on 2013 Curriculum. Journal of English Language and Pedagogy, 2(1), 1-7. https://doi.org/http://dx.doi.org/10.36597/j elp.v2i1.3703

Shangarffam, N., \& Ghazi Saeedi, F. (2013). The relationship among EFL learners' autonomy, first language essay writing tasks and second language essay writing tasks in task/content based language instruction. Global Journal of Science, Engineering and Technology, System, 5, 177-191.

Tian, D., \& Chunlei, X. (2005). Fostering learner autonomy in English language classroom. CELEA Jour, 28(3), 100-104. https://doi.org/10.1016/j.sbspro.2015.07.4 91

Tomlinson, B. (2008). English language learning materials: A critical review. Bloomsbury Publishing. 